\title{
Guillain-Barré Syndrome after Streptokinase Therapy for Acute Myocardial Infarction
}

\author{
Ahad Eshraghian ${ }^{1}$, Hamed Eshraghian ${ }^{1}$ and Kamran Aghasadeghi ${ }^{2}$
}

\begin{abstract}
Some drugs including streptokinase have been reported to precipitate Guillain-Barré syndrome. We report a 70-year-old man with acute anterior myocardial infarction who developed Guillain-Barré syndrome seven days after thrombolytic therapy with streptokinase.
\end{abstract}

Key words: Guillain-Barré syndrome, myocardial infarction, streptokinase

(Intern Med 49: 2445-2446, 2010)

(DOI: 10.2169/internalmedicine.49.3900)

\section{Introduction}

Guillain-Barré syndrome is an acute immune-mediated polyneuropathy caused by infection, inflammation and surgery (1). Some medications including streptokinase have been reported to precipitate Guillain-Barré syndrome. Here, we report a case of Guillain-Barré syndrome seven days after receiving streptokinase for acute myocardial infarction (MI).

\section{Case Report}

The patient was a 70-year-old obese man presented to our emergency room with chest pain radiating to the left shoulder and accompanied with dyspnea. Electrocardiogram showed ST elevation in $\mathrm{V}_{2}-\mathrm{V}_{4}$ precordial leads. Troponin-I was positive and creatine kinase-MB level was elevated to $5.4 \mathrm{ng} / \mathrm{mL}$. The patient received 1.500000 units of streptokinase and was discharged, in good general condition 5 days after CCU admission.

Seven days after discharge, he returned again complaining of general lethargy and the sensation of pins and needles in his hands and feet from the previous day. The patient then developed progressive muscle weakness of his lower extremities as well as distal sensory impairment. On physical examination the muscle power of extremities was decreased and the patient had areflexia. The patient was conscious and alert and fundoscopy was normal. Blood cell counts and results of biochemistry tests were within the normal range. Brain computed tomography was normal. The patient was admitted in the intensive care unit (ICU) with clinical suspicion of Guillain-Barré syndrome. Cerebrospinal fluid (CSF) analysis revealed a cell count 4 cells $/ \mathrm{mm}^{3}$, protein $90 \mathrm{mg} / \mathrm{dL}$ and CSF-to-serum glucose ratio of 0.65 . The patient then developed respiratory failure and was intubated and connected to a ventilator. Nerve conduction velocity showed these findings: 1. Absent bilateral $\mathrm{H}$. reflex and low frequency F. waves, 2. Absent sensory nerve action potential (SNAP) of bilateral median, ulnar and superficial proneal (SPN) nerves, and 3. Absent nerve conduction velocity of deep proneal (DPN) and ulnar nerves. These findings were in favor of acute generalized peripheral sensory motor polyneuropathy. The patient was treated with plasmaphresis every other day for 5 times. He also received 5 doses of intravenous immunoglobulin (IVIG). His condition gradually improved and one month later he was discharged from hospital with muscle power returning to 3 of 5 in all extremities.

\section{Discussion}

The precise cause of Guillain-Barré syndrome is not yet known but it has been reported to be associated with viral infections, lupus erythematous, lymphoma, Hodgkin's disease and other situations (1) and the underlying mechanism

${ }^{1}$ Department of Medicine, Shiraz University of Medical Science, Iran and ${ }^{2}$ Department of Cardiology, Shiraz University of Medical Science, Iran

Received for publication May 1, 2010; Accepted for publication July 27, 2010

Correspondence to Dr. Ahad Eshraghian, Eshraghiana@yahoo.com 
Table 1. Reports of Guillain Barré Syndrome after Streptokinase Therapy

\begin{tabular}{lccc}
\hline Paper & $\begin{array}{c}\text { Number of } \\
\text { Patients }\end{array}$ & $\begin{array}{c}\text { Cause for thrombolytic } \\
\text { Therapy }\end{array}$ & Year \\
\hline Eden KV (2) & 1 & Axillary vein thrombosis & 1983 \\
Leaf DA et al. (3) & 1 & MI & 1984 \\
Cicale MJ (4) & 1 & Pulmonary embolism & 1987 \\
Roquer J et al. (5) & 1 & MI & 1990 \\
Barnes D et al. (6) & 1 & MI & 1992 \\
Ancillo P et al. (7) & 1 & MI & 1994 \\
Taylor VT et al. (8) & 2 & MI/ Pulmonary embolism & 1995 \\
\hline
\end{tabular}

is probably immunological.

Here, we report a case of anterior MI that developed Guillain Barré syndrome seven days after receiving streptokinase. Although this is not the first case, streptokinase and other thrombolytic agents are rarely reported in the literature as precipitants of Guillain-Barré syndrome (Table 1). There are also reports of Guillain-Barré syndrome after MI in patients without thrombolytic therapy $(9,10)$.

Therefore, it is not well determined whether the process of MI itself is the promoter of poly neuropathy or thrombolytic agents are initiators of this condition.

Streptokinase is a single chain polypeptide extracted from beta hemolytic streptococci. The protein nature of this drug makes it antigenic in the body and thus can stimulate immunologic reactions (11). This is probably the pathophysiologic basis in the development of Guillain-Barré syndrome after streptokinase therapy. Kaiser et al found that serum titers of immunoglobulin were elevated 64-fold for $\mathrm{IgG}, 16$-fold for IgM, and 4-fold for IgA compared to controls after streptokinase therapy (12). Others have argued against an association of Guillain-Barré syndrome and streptokinase therapy based on its low incidence (13).

Although streptokinase has been abrogated in a considerable number of countries, it is still routinely used in many developing countries. Therefore this rare condition should be kept in mind as one of the complications of streptokinase.

\section{References}

1. Hahn AF. The Guillain-Barré syndrome. Lancet 352: 635, 1998.

2. Eden KV. Possible association of Guillain-Barre syndrome with thrombolytic therapy. JAMA 249: 2020-2021, 1983.

3. Leaf DA, MacDonald I, Kliks B, Wilson R, Jones SR. Streptokinase and the Guillain-Barre syndrome. Ann Intern Med 100: 617, 1984.

4. Cicale MJ. Guillain-Barre syndrome after steptokinase therapy. South Med J 80: 1068, 1987.

5. Roquer J, Herraiz J, Arnau D, Serrat R. Guillain-Barré syndrome after streptokinase therapy. Acta Neurol Scand 82: 153, 1990.

6. Barnes D, Hughes RA. Guillain-Barré syndrome after treatment with streptokinase. Br Med J 304: 1225, 1992.

7. Ancillo P, Duarte J, Cortina JJ, Sempere AP, Clavería LE. Guillain-Barré syndrome after acute myocardial infarction treated with anistreplase. Chest 105: 1301-1302, 1994.

8. Taylor VT, Mastaglia FL, Stell R. Guillain-Barré syndrome complicating treatment with streptokinase. Med J Aust 162: 214-215, 1995.

9. McDonagh AJG, Dawson J. Guillain-Barre syndrome after myocardial infarction. BMJ 294: 213-214, 1987.

10. Ng E, Stafford PJ. Guillain-Barré syndrome after myocardial infarction. Int J Cardiol 90: 129-130, 2003.

11. Anderson HV, Willerson JT. Thrombolysis in acute myocardial infarction. N Engl J Med 329: 703, 1993.

12. Kaiser R, Kaufmann R, Czygan M, Lang H, Lucking $\mathrm{CH}$. Guillain-Barré syndrome following streptokinase therapy. Clin Invest 71: 795-801, 1993.

13. Arrowsmith JB, Milstein JB, Kuritsky JN, Murano G. Streptokinase and the Guillain-Barre syndrome. Ann Intern Med 103: 302, 1985.

(C) 2010 The Japanese Society of Internal Medicine http://www.naika.or.jp/imindex.html 